\title{
Reversal of precedence: The oldest available name of the Javan gibbon and a complete synonymy of the species
}

\author{
Kai R. Caspar ${ }^{1}$
}

Received: 29 January 2020 / Accepted: 11 April 2020 / Published online: 24 April 2020

(c) The Author(s) 2020

\begin{abstract}
Over the course of their long research history, a plethora of scientific names have been applied to the different species of apes (Hominoidea). Although numerous authors, past and present, have attempted to reconstruct hominoid nomenclatural history in detail, it appears that parts of it, mostly concerning the lesser apes or gibbons, still remain overlooked. Here I show that Simia Nanodes Lichtenstein, 1791 is a senior synonym of Simia Moloch Audebert, 1797, otherwise regarded as the oldest binomen applicable to the Javan gibbon. However, since Simia Nanodes failed to enter common usage, these names are subject to a reversal of precedence as defined by Article 23.9 of the International Code of Zoological Nomenclature. Simia Moloch Audebert, 1797 must be maintained as a nomen protectum, resulting in Hylobates moloch (Audebert, 1797) staying the valid name of the species. Simia Nanodes Lichtenstein, 1791 is declared a nomen oblitum. In compliance with this, I provide a complete scientific synonymy of the Javan gibbon and comment on its early research history.
\end{abstract}

Keywords Nomenclature $\cdot$ Reversal of precedence $\cdot$ Hylobates moloch $\cdot$ Synonymy $\cdot$ Nomen oblitum $\cdot$ History of primatology

The history of primate research and nomenclature is the subject of ongoing scientific discussion, with that of apes (Hominoidea) being of particular concern. In the case of great apes (Hominidae) this interest continues to regularly spawn new monographs (e.g., Ingensiep 2013; Herzfeld 2017), at times still resulting in nomenclatural revisions (Oates et al. 2009). Compared to that, the lesser apes or gibbons (Hylobatidae) appear to be covered only superficially. In recent times, their research history, including nomenclature, was most importantly discussed and analyzed by Groves (1972, 2008) but otherwise received only poor attention.

The Javan or silvery gibbon, Hylobates moloch (Audebert 1797) (Fig. 1a), is a well-studied species of lesser ape, whose research history spans several centuries. It is exclusively found on Java and is the only extant hylobatid

Electronic supplementary material The online version of this article (https://doi.org/10.1007/s10329-020-00822-5) contains supplementary material, which is available to authorized users.

Kai R. Caspar

kai.caspar@uni-due.de

1 Department of General Zoology, Faculty of Biology, University of Duisburg-Essen, Essen, Germany inhabiting the island. For decades, Simia Moloch Audebert, 1797 has been universally accepted as the oldest available name for this species, as established by Cabrera (1930). However, mentions of Javan gibbons significantly predate the description by Audebert (1797). The earliest reference at times attributed to the Javan gibbon dates to the latest 17th century (Le Comte 1696) but its ambiguous geographical and morphological descriptions make it impossible to confidently assign this report to one particular species of lesser ape. The first unequivocal references to Javan gibbons were only provided several decades later. Pennant (1771) mentioned a gibbon in the possession of Lord Clive that was "good-natured, and full of frolick". It was described as having a silvery pelage with a black cap and therefore surely was a Javan gibbon. More detailed reports on the species were provided by contemporary Dutch scholars, while Java was controlled by the Dutch East India company. Most notably, Van Iperen and Schouwman (1780) but also Camper $(1779,1782)$ wrote about its natural history and anatomy. Van Iperen and Schouwman (1780) were the only European scholars of the 18th century that gave detailed first-hand accounts of living Javan gibbons, which they observed in captive settings while staying on the island. They not only provided accurate descriptions of their appearance but also 

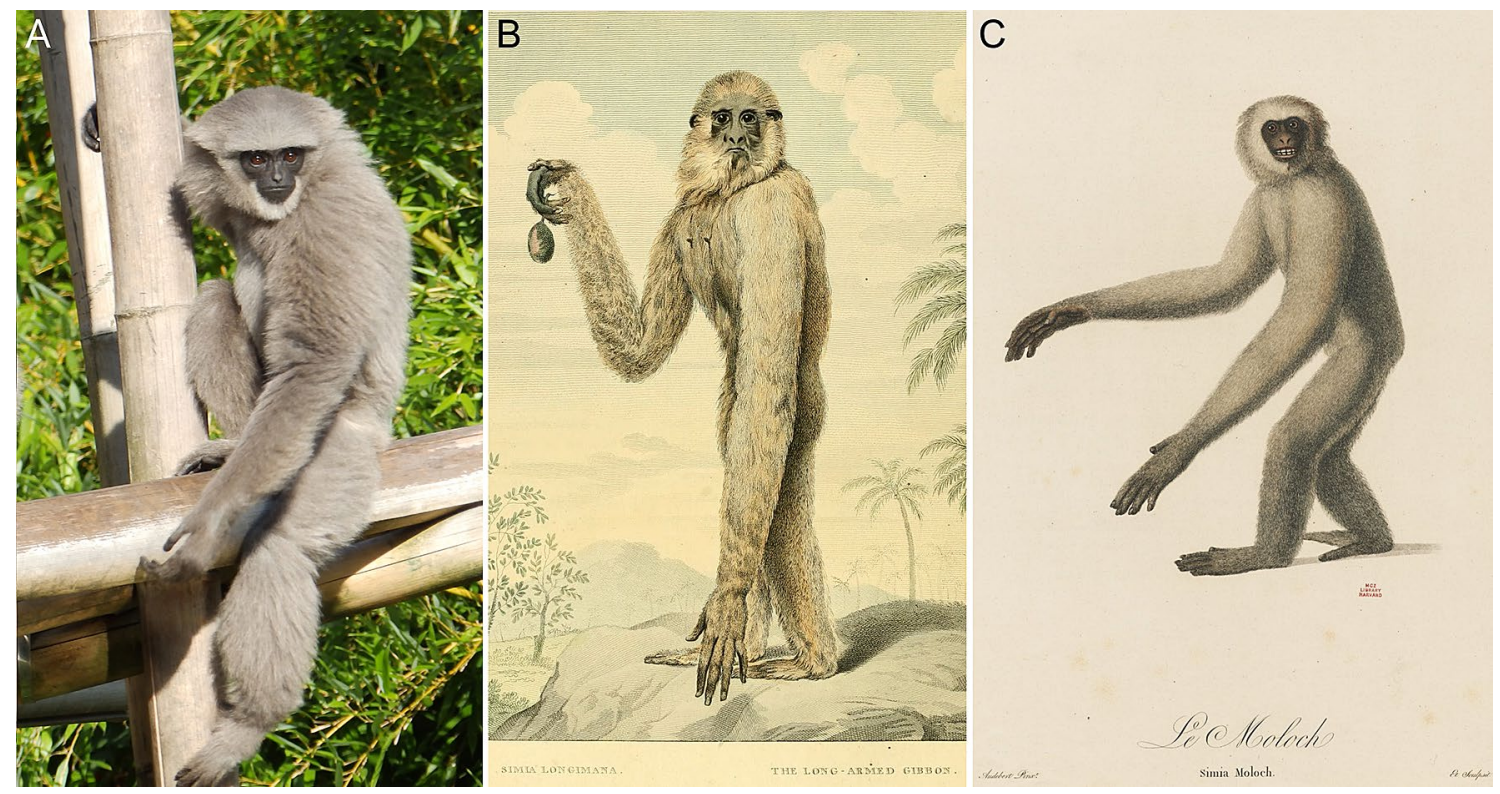

Fig. 1 The Javan gibbon and early scientific illustrations of it. a Captive subadult Javan gibbon. Photograph by K. R. Caspar. b Possibly the oldest surviving artistic depiction of the species by Western authors from Shaw (1792) (Van Iperen and Schouwman (1780) hint at older ones drawn from live in Java), showing a stuffed female specimen from the since disintegrated Leverian collection in London in an imaginative landscape. The animal is wrongly identified as a white-handed gibbon (=Simia longimana) in the picture caption. c Type illustration of Simia Moloch from Audebert (1797) based on

reported on behavioral aspects and folkloristic knowledge about the species. Furthermore, they presented a list of anatomical measurements from two adult Javan gibbons. By the early 1780 s, multiple specimens had been sent to Europe. Some were housed in the Dutch Stadholder's collection in the Hague and in the Museum Leverianum in London (Camper 1782). An adult female specimen in the Leverian collection stood model for what might be the oldest surviving illustration of the species (Shaw 1792; Fig. 1b, later redrawn by Pennant (1793) whose depiction was copied by Schreber (1799)). Van Iperen and Schouwman (1780) suggested that the Javan gibbon represented a different species from the "gibbon of Buffon" (now Hylobates lar (Linnaeus, 1771), the white-handed or lar gibbon), the first small ape known to science (Buffon 1766), but refrained from providing a binomen for it. Neither did Camper (1782), who unified the two. Instead, these authors used the name Wouwouw or Wou-wou when referring to the ape, an onomatopoeic expression alluding to its characteristic vocalizations. In the late 18th and early 19th centuries, this trivial name was applied only to the Javan gibbon, but some scholars later extended it to the agile gibbon, Hylobates agilis F. Cuvier, 1821 (Martin 1841).

The first author who referenced the Wou-wou in connection with an available binomial name was the German the lectotype of the Javan gibbon preserved at the Muséum National d'Histoire Naturelle in Paris (MNHN-ZM-2005-970). All individuals depicted only show traces of the black cap that is typically expressed in the species. The missing caps in the oldest illustrations of Javan gibbon specimens led to now settled disputes about their species identity (Matschie 1893; Groves 1972). Images from Shaw (1792) and Audebert (1797) in public domain, made available by the Biodiversity Heritage Library

scholar Anton August Heinrich Lichtenstein in his 1791 dissertation (year of publication verified e.g., by Brockhaus (1825)), several years before Audebert's widely recognized treatise. His work was titled "Commentatio philologica de simiarum quotquot veteribus innotuerunt formis earumque nominibus pro specimine methodi qua historia naturalis veterum ad systema naturae linnaeanum exigenda atque adornanda" (when cited often abbreviated as "De simiis veterum"), and was released by the publishing house of Benjamin Gottlob Hoffmann. Therein, Lichtenstein (1791) reviewed references to primates in ancient Greek and Roman literature and tried to link them to the scientifically recognized species of his time. He eventually presented a synonymy of primate names, listing the species he deemed valid in compliance with the Linnean system, applying appropriate binomina. He distinguished the Javan gibbon from both the orangutan and the white-handed gibbon and named it Simia Nanodes, dwarf ape, etymologically inspired by a section in Aristotle's De partibus animalium on "dwarves". Although he concluded that ancient European scholars probably had knowledge of the white-handed gibbon (he interpreted the onocentaur beast from Claudius Aelianus' De natura animalium as a transfigured lar gibbon), he doubted that they knew about the existence of the Javanese species. Nowadays, it is assumed that ancient 
Western authors did not have any notion of gibbons in general (Groves 2008).

Lichtenstein (1791) added the following brief description to his Simia Nanodes:

Ecaudis, natibus calvis, brachiis longitudine corporis, capite obovato, facie nigra triangulari, serie pilorum ex albo cinereorum circumdata. [Tailless, naked buttocks (referring to ischial callosities), arms as long as body, head obovate, face black and of triangular shape, framed by whitish-gray hair.]

Still, he pointed at the possibility that Javan and lar gibbon might at some point be identified as representatives of one morphologically variable species. The description was not accompanied by an illustration. As a locality for Simia Nanodes he provided:

Habitat in India, praefertim in Java. [Habitat in India (meaning South East Asia), preferably Java].

He further stated that "wouwou" and "wauwau" (the latter being the Germanized spelling of the former) are nonscientific terms referring to this species and cites a German translation (Von Wurmb 1783) of the treatise by Van Iperen and Schouwman (1780) as the principal source of information for his description. All that makes the identification of Simia Nanodes as the Javan gibbon unequivocal. In consequence, Simia Nanodes Lichtenstein, 1791 is a senior synonym of Simia Moloch Audebert, 1797. However, this case represents a reversal of precedence as defined in Article 23.9 of the International Commission on Zoological Nomenclature, preventing the older name to be used (ICZN 1999). To my best knowledge, Lichtenstein's name has not been referenced to as valid in the scientific literature after 1899 (Article 23.9.1.1), while the one of Audebert has been universally accepted as such for decades (Article 23.9.1.2; see electronic supplement). Therefore, in compliance with the code, prevailing usage of Hylobates moloch (Audebert, 1797) must be maintained and Simia Moloch Audebert, 1797 is defined as a nomen protectum for the Javan gibbon. The senior synonym Simia Nanodes Lichtenstein, 1791 is herein declared a nomen oblitum.

Lichtenstein was a philologist interested in the conceptional history of primatology rather than a zoologist (despite being well versed in natural history), which could be the reason why his naming of the Javan gibbon remained undetected by the contemporary authorities on primates. It was, however, cited and in parts commented on by several German-speaking authors, most noteworthy Ludwig (1796), who incorrectly deemed one of the gibbons described by Buffon (1766) to be a member of the Javanese species. Nevertheless, just a few years after its publication, Lichtenstein's name started to vanish from the literature. It was possibly last mentioned by Lesson (1840), who erroneously included Sinia nanodes [sic] in his synonymy of Hylobates variegatus (= Hylobates lar (Linnaeus, 1771)).
Unaffected by the reversal of precedence, the namebearing type of the Javan gibbon remains a mounted specimen preserved at the Muséum National d'Histoire Naturelle in Paris (specimen number: MNHNZM-2005-970; photograph in Hendriksen (2019)). It was prominently illustrated alongside Audebert's (1797) description (Fig. 1c), which also indicates one nondepicted syntype, and was designated as a lectotype by Rode (1938) (he referred to it as a holotype, which is an invalid assignment according to Article 73.1.3 (ICZN 1999) since it has not been designated as such by the species' describer). Originally, the lectotype specimen derives from the Dutch Stadholder's collection that was curated by Arnout Vosmaer (Rode 1938; Hendriksen 2019). The latter is also known to have requested gibbons from the Royal Batavian Society for the Stadholder's menagerie. However, all animals sent to him from Java apparently did not survive the passage (Van Iperen and Schouwman 1780). Whether the lectotype specimen was initially intended to be presented alive at the Dutch menagerie remains obscure. It eventually arrived in Paris following the seizure of the Stadholder's collection by French authorities in 1795, shortly after the defeat of the Dutch republic in the Coalition wars (Lipkowitz 2014; Hendriksen 2019).

Below, I provide an updated synonymy of Hylobates moloch (Audebert, 1797) following stylistic recommendations by Gardner and Hayssen (2004). Lichtenstein's Simia Nanodes is a further addition to the already complex nomenclatural history of the Javan gibbon, which was analyzed by Groves $(1971,1972)$ and Kappeler (1981). The now established name combination Hylobates moloch was first used by Frechkop (1934), a few years after it had been suggested as the Javan gibbon's valid name by Cabrera (1930). It eventually gained more prominence after being employed by Chasen (1940) in his Handlist of Malaysian Mammals. However, Chasen (1940), in contrast to Cabrera (1930) and Frechkop (1934), subspecifically included Bornean (now commonly referred to as $H$. muelleri Martin, 1841 and $H$. albibarbis Lyon, 1911) as well as Javan gibbons into $H$. moloch, the taxonomic histories of which had long been intertwined (reviewed by Groves 1971). Only in the late 1970s and 1980s was this name increasingly used to refer to the Javan gibbon exclusively as a full species (Marshall and Marshall 1976; Chivers and Gittins 1978; Marshall and Sugardjito 1986). Before that, Javan gibbons were also frequently viewed as a subspecies of Hylobates lar (e.g., Groves 1972). Potential subspecific differentiation within the Javan gibbon and its nomenclatural implications were discussed by Dallmann and Geissmann (2009) but are not considered in the synonymy. Names designated to other gibbon species that were at times associated with $H$. moloch, as well as subgeneric assignments have been ignored. 


\section{Hylobates moloch (Audebert, 1797)}

Simia Nanodes Lichtenstein, 1791:31. Type locality "India praefertim in Java". Nomen oblitum.

Simia Moloch Audebert, 1797: plate II. Type locality "Il habite les Moluques". Restricted to "Tjianten, Mt. Salak, ca. 1100 m" by Sody, 1949:121). Nomen protectum.

Simia cinerea Cuvier, 1798:96 Type locality "De Batavia". Preoccupied by Simia cinerea Kerr, 1792 (=Mandrillus leucophaeus).

Simia Leucisca Schreber, 1799: plate III B (actual publication year unknown, dated according to Sherborn (1892)). Type locality unknown. No description but artistic depiction.

Pit.[Pithecus] cinereus: Latreille, 1804:277. New name combination.

? Simia hirsuta Forster, mentioned in Sonnerat, 1806:81. Type locality unknown. Nomen nudum. (This citation derives from a reissue, the first edition of which is unavailable to the author.)

Pithecus leuciscus: Geoffroy Saint-Hilaire, 1812:89. New name combination.

S.[Satyrus] Leuciscus: Oken, 1816:1226. New name combination.

Hylobates leuciscus: Kuhl, 1820:6. New name combination. Not Hylobates leuciscus Matschie, 1893: 62 (=Hylobates muelleri abbotti).

Cheiron Leuciscus: Burnett, 1829:307. New name combination.

H.[Hybolates] Leusiscus Geoffroy Saint-Hilaire, 1834:34. Incorrect subsequent spelling of Hylobates leuciscus Kuhl, 1820.

H.[Hylobates] leucurus Gray, 1861:136. Incorrect subsequent spelling of Hylobates leuciscus Kuhl, 1820.

Hylobates javanicus Matschie, 1893:62. Type locality "Java".

Hylobates lar leuciscus: Pocock, 1927:727. New name combination.

Hylobates cinereus cinereus: Kloss, 1929:119. New name combination.

Hylobates moloch: Frechkop, 1934:23. First use of current name combination (already alluded to but not written out in Cabrera, 1930).

Hylobates moloch moloch: Chasen, 1940:64. New name combination.

Hylobates lar moloch: Sody, 1949:121. New name combination.

Hylobates lar pongoalsoni Sody, 1949:123 Type locality "Kali Kidang, Mount Slamat, C[entral]. Java, 800 m". At times considered a subspecies (H. moloch pongoalsoni) (but see Dallmann and Geissmann (2009)).

Acknowledgements I would like to thank Ato Schweizer for helpful suggestions on literature research, Sabine Begall for critical reading of the manuscript, and Elsa Marlene Vorderwülbecke for giving advice on translations from French. The Biodiversity Heritage Library is acknowledged for providing free access to numerous texts and images that were essential for the preparation of this work. I am also grateful to two anonymous reviewers whose comments markedly improved the manuscript. Open Access funding was provided by Projekt DEAL.

Funding The author was supported by a $\mathrm{PhD}$ fellowship of the German National Academic Foundation (Studienstiftung des deutschen Volkes).

\section{Compliance with ethical standards}

Conflicts of interest The author declares no conflict of interest.

Open Access This article is licensed under a Creative Commons Attribution 4.0 International License, which permits use, sharing, adaptation, distribution and reproduction in any medium or format, as long as you give appropriate credit to the original author(s) and the source, provide a link to the Creative Commons licence, and indicate if changes were made. The images or other third party material in this article are included in the article's Creative Commons licence, unless indicated otherwise in a credit line to the material. If material is not included in the article's Creative Commons licence and your intended use is not permitted by statutory regulation or exceeds the permitted use, you will need to obtain permission directly from the copyright holder. To view a copy of this licence, visit http://creativecommons.org/licenses/by/4.0/.

\section{References}

Audebert JB (1797) Histoire Naturelle des Singes et des Makis. Desray, Paris

Brockhaus FA (1825) Conversations-Lexicon in zwei Bänden. K - R, und im Anhange Artikel über die katholischen Glaubenslehren von M - W. Brockhaus, Leipzig

Buffon GL (1766) Histoire naturelle, générale et particulière avec la description du cabinet du roi, vol 14. De l'imprimerie royale, Paris

Burnett GT (1828) Illustration of the Manupeda, or apes and their allies, being the arrangement of the Quadrumana or anthropomorphous beasts indicated in outlined. Q J Sci Lit Arts 26:301-307

Cabrera A (1930) A note on the name of the Javanese gibbon. Proc Zool Soc Lond 1930:257

Camper P (1779) Kort berigt wegens de ontleding van verscheidene orang outangs, en inzonderheid van die in de diergaarde van zyne doorluchtigste hoogheid, den heere Prinse van Orange, Erfstadhouder, enz. enz. enz. gestorven is, in den jaare 1777. Alg Vaderl Letter-Oefen. 1:18-36

Camper P (1782) Natuurkundige verhandelingen van Petrus Camper over den orang outang en eenige andere aapsoorten, over den rhinoceros met den dubbelen horen en over het rendier, P Meijer \& G Warnars, Amsterdam

Chasen FN (1940) A handlist of Malaysian mammals. Bull Raffles Mus 15:1-209

Chivers DJ, Gittins SP (1978) Diagnostic features of gibbon species. Int Zoo Yearb 18:157-164

Cuvier G (1798) Tableau élémentaire de l'histoire naturelle des animaux. Baudouin, Paris

Dallmann R, Geissmann T (2009) Individual and geographical variability in the songs of wild silvery gibbons (Hylobates moloch) on Java, Indonesia. In: Lappan SM, Whittacker D (eds) The gibbons: new perspectives on small ape socioecology and population biology. Springer, New York, pp 91-110 
Frechkop S (1934) Notes sur les Mammifères. XVI. Les Mammifères rapportés, en 1932, de l'Extrême-Orient par S.A.R. le Prince Léopold de Belgique. Bull Mus Roy Hist Nat Belgique 10:1-37

Gardner AL, Hayssen V (2004) A guide to constructing and understanding synonymies for mammalian species. Mamm Species 739:1-17

Geoffroy Saint-Hilaire E (1812) Tableau des Quadrumanes. Ann Mus Hist Nat Paris 19:85-122

Geoffroy Saint-Hilaire E (1834) Histoire naturelle des mammifères: comprenant quelques vues préliminaires de philosophie naturelle et l'histoiren des singes, des makis, des chauve-souris, et de la taupe. De Just Rouvier \& E Le Bouvier, Paris

Gray JE (1861) List of Mammalia, tortoises and crocodiles collected by M. Mouhot in Cambodia. Proc Zool Soc Lond 1861:135-140

Groves CP (1971) Geographic and individual variation in Bornean gibbons, with remarks on the systematics of the subgenus Hylobates. Folia Primatol 14:139-153

Groves CP (1972) Systematics and phylogeny of gibbons. In: Rumbaugh (ed) Gibbon and Siamang, vol 1. Evolution, ecology, behavior, and captive maintenance. S. Karger, Basel, pp 1-89

Groves CP (2008) Extended family: long lost cousins: a personal look at the history of primatology. Conservation International, Arlington

Hendriksen MM (2019) Animal bodies between wonder and natural history: taxidermy in the cabinet and menagerie of Stadholder Willem V (1748-1806). J Soc Hist 52:1110-1131

Herzfeld C (2017) The great apes: a short history. Yale University Press, New Haven

International Commission on Zoological Nomenclature (1999) International Code of Zoological Nomenclature. Ride WDL, Cogger HG, Dupuis C, Kraus O, Minelli A, Thompson FC, Tubbs PK (eds), 4th edn. International Trust for Zoological Nomenclature

Ingensiep HW (2013) Der kultivierte Affe: Philosophie, Geschichte und Gegenwart. S Hirzel, Stuttgart

Kappeler M (1981) The Javan silvery gibbon (Hylobates lar moloch). $\mathrm{PhD}$ Dissertation, University of Basel

Kloss CB (1929) Some remarks on the gibbons, with the description of a new sub-species. Proc Zool Soc Lond 1929:113-127

Kuhl H (1820) Beiträge zur zoologie und vergleichenden anatomie. Hermannsche Buchhandlung, Frankfurt

Latreille PA (1804) Tableau méthodique des singes. In: Sonnini CS (ed) Histoire Naturelle Générale et Particulière, par Leclerc de Buffon. Dufart, Paris, pp 275-298

Le Comte LD (1696) Nouveaux memoires sur I'etat present de la Chine, vol 2. Desbordes, Amsterdam

Lesson RP (1840) Species des mammifères bimanes et quadrumanes: suivi d'un mémoire sur les Oryctéropes. JB Baillière, Paris

Lichtenstein AAH (1791) Commentatio philologica de simiarum quotquot veteribus innotuerunt formis earumque nominibus pro specimine methodi qua historia naturalis veterum ad systema naturae linnaeanum exigenda atque adornanda. BG Hoffmann, Hamburg

Lipkowitz ES (2014) Seized natural-history collections and the redefinition of scientific cosmopolitanism in the era of the French Revolution. Br J Hist Sci 47:15-41

Ludwig CF (1796) Grundriß der Naturgeschichte der Menschenspecies, für akademische Vorlesungen. Schwickertscher Verlag, Leipzig

Marshall JT, Marshall ER (1976) Gibbons and their territorial songs. Science 193:235-237
Marshall JT, Sugardjito J (1986) Gibbon systematics. In: Swindler DR, Erwin J (eds) Comparative primate biology: systematics, evolution, and anatomy, vol 1. AR Liss, New York, pp 137-185

Martin WCL (1841) A general introduction to the natural history of mammiferous animals: with a particular view of the physical history of man, and the more closely allied genera of the order quadrumana or monkeys. Wright and Co. Printers, London

Matschie P (1893) Zwei von Schreber beschriebene Affen und einige anscheinend neue Säugtiere von Afrika. Sber Ges naturf Freunde Berl 1893:60-62

Oates JF, Groves CP, Jenkins PD (2009) The type locality of Pan troglodytes vellerosus (Gray, 1862), and implications for the nomenclature of West African chimpanzees. Primates 50:78-80

Oken L (1816) Okens Lehrbuch der Naturgeschichte. Dritter Theil, Zoologie. Zweite Abtheilung, Fleischthiere. A Schmid \& Comp., Jena

Pennant T (1771). Synopsis of quadrupeds. J Monk, Chester

Pennant T (1793). History of quadrupeds, Vol 1. 3rd edn. B \& J White, London

Pocock RI (1927) The gibbons of the genus Hylobates. Proc Zool Soc Lond 1927:719-741

Rode P (1938) Catalogue des Types de Mammifères du Muséum National d'Histoire Naturelle (Simiens). Bull Mus Natl Hist Nat 10:202-251

Schreber JCD (1799) Die Säugthiere in Abbildungen nach der Natur, mit Beschreibungen. Theil V, Part I, Heft 56-57. W Walther, Erlangen, pp 56-57

Shaw G (1792) Museum Leverianum, containing select specimens from the museum of the late Sir Ashton Lever: with descriptions in Latin and English, vol 1. J Parkinson, London

Sherborn CD (1892) On the dates of the parts, plates, and text of Schreber's 'Säugthiere'. Proc Zool Soc Lond 1891:587-592

Sody HJV (1949) Notes on some primates, carnivora, and the babirusa from the Indo-Malayan and Indo-Australian regions. Treubia 20:121-190

Sonnerat $\mathrm{P}$ (1806) Voyage aux Indes orientales et à la Chine : fait par ordre de Louis XVI, depuis 1774 jusqu'en 1781; dans lequel on traite des moeurs, de la religion, des sciences et des arts des Indiens, des Chinois, des Pégouins et des Madégasses; suivi d'observations sur le Cap de Bonne-Espérance, les Isles de France $\&$ de Bourbon, les Maldives, Ceylan, Malacca, les Philippines \& les Moluques, $\&$ de recherches sur l'histoire naturelle de ces pays, vol 4, 2nd ed. Dentu, Paris

Van Iperen J, Schouwman F (1780) Beschryvinge van de wou-wouwen. Verh Batav Genootsch Konsten 1784:383-415

Von Wurmb FL (1783) Beschreibung der Wauwauwen. Auszugsweise aus dem Holländschen des zweyten Theils der "Verhandelingen van het Bataviaasch Genootschap der Kunsten en Weetenschappen". Mag Neueste Phys Naturgesch 5:1-17

Publisher's Note Springer Nature remains neutral with regard to jurisdictional claims in published maps and institutional affiliations. 